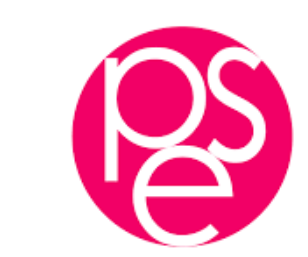

PARISSCHOOLOFECONOMICS
ECOLED'ECONOMIE DE PARIS

WORKING PAPER N $2020-65$

Taylor Rules and liquidity in financial markets

\title{
Emanuele Franschi
}

JEL Codes:

Keywords:

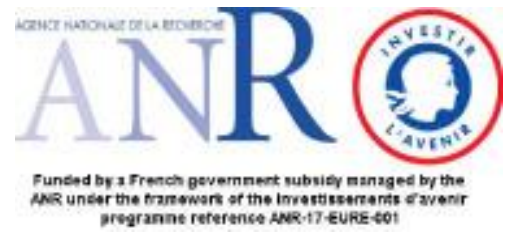




\title{
Taylor Rules and liquidity in financial markets
}

\author{
Emanuele Franceschi * \\ PSE - Paris School of Economics \\ Université Paris 1 Panthéon-Sorbonne
}

This version: October 22, 2020

\begin{abstract}
We study the parameter instability in the monetary policy rule followed by the US Federal Reserve Bank since WWII. We find evidence across a variety of econometric methods of fundamental instability, in particular on the parameter governing the reaction to inflation expectations - the Taylor Principle. We augment the monetary policy rule to account for liquidity conditions and find consistent violations of the Taylor Principle without sunspot inflation episodes. We study the presence of multiple regimes and find that when uncertainty and economic slowdown are looming the Fed reacts passively to expected inflation.
\end{abstract}

\section{Introduction}

Before the Global Financial Crisis (GFC), there was wide consensus that the central bank could stabilize inflation and the real economy by following a Taylor-rule type monetary policy (Taylor, 1993). Such rule, as emphasized by the literature on determinacy of equilibria and feedback interest rate rules, would also insulate the economy from erratic expectations unrelated to market fundamentals (Gali, 2015; Walsh, 2003; Woodford, 2003). Even though there were some criticisms about the theoretical foundations of these views (Cochrane, 2011), economists and policymakers were confident on the virtues of the Taylor rule. Furthermore, financial stability, liquidity of financial assets, or financial conditions in general, including quantitative measures of money and credit, had no relevance in the monetary policy conduct, and their consideration was discouraged because of the difficult identification of bubbles or excessive risk taking (Bernanke, 2002; Greenspan, 2002). The GFC fundamentally challenged the existing consensus. Once interest rates hit the zero lower bound, the Taylor principle was violated, as interest rates could no longer respond to the behaviour of the economy. The US Federal Reserve Bank (and subsequently other

*I thank seminar participants at PSE Macro Workshop, 2019 GDRe Symposium in Besançon and $5^{\text {th }}$ IMAC workshop. H. Bennani and G. l'Oeillet provided excellent discussion. I wish to thank F. Coricelli and J-B. Chatelain for invaluable guidance. I also wish to thank M. Ranaldi, I. Iodice, J. Montana, and F. Ceron for fruitful conversations. All errors remain my own.

Contact: emanuele.franceschi@psemail.eu 
major central banks in the world) resorted to unconventional monetary tools, such as liquidity injections in the financial system (Quantitative Easing rounds, QE). Interestingly, in spite of the a violation of the Taylor Principle, inflation did not show an erratic behaviour as implied by workhorse New Keynesian Dynamic Stochastic General Equilibrium models (NKDSGEs) (Cochrane, 2018). Moreover, the assumption in NKDSGEs that the policy interest rate is essentially an interest on a pure, illiquid, bond began to appear awkward (Calvo, 2016; B. Diba and Loisel, 2017; Hall and Reis, 2016). Introducing liquidity considerations and the fact that the policy rate might be an interest rate on money or liquid assets rather than pure bonds, drastically modifies the properties of the model and especially the implications of the Taylor rule for determinacy. Specifically, the fact that the Taylor principle is necessary to induce determinacy and thus that it is necessary and sufficient to anchor inflationary expectations, does not apply anymore. In light of the fundamental issues raised by the GFC, the revisitation of the actual implementation of the Taylor rule appear warranted and compelling.

In this paper we investigate the behaviour of the Fed in the whole post WWII period in the framework of the Taylor rule. We evaluate the monetary policy conduct focusing on the interplay between inflation response - embodied in the Taylor Principle (TP) - and liquidity in the financial system, measured as a spread between safe assets and less liquid assets. In a nutshell, we find that financial conditions affect monetary policy conduct of the Fed, since Central Bank consistently deviates from the Taylor Principle when financial liquidity is included in the Taylor rule. Moreover, we report instability in the policy rule and therefore investigate the presence of multiple regimes. When considering a standard Taylor rule with real time data, we do not find deviations from the TP even in periods of high inflation. On the other hand, when we include proxies for liquidity we find regimes in which the Fed lowers the weight of expected inflation, hence in violation of the TP, in favour of financial liquidity.

We contribute and relate to a vast literature. On the empirical part we confront the exogenous regime definition of Clarida, Gali, and Gertler (2000), we also make preferably use of real-time data, whose importance has been shown by Orphanides $(2001,2004)$. In studying how the monetary policy rule has evolved over time we consider the insights from Boivin (2006), Canova and Sala (2009), Primiceri (2005), and Sullivan (2016), and finally follow Davig and Leeper (2006, 2011), Murray, Nikolsko-Rzhevskyy, and Papell (2015), and Sims and Zha (2006) in adopting a Markov Switching model approach to let the data speak as freely as possible. Concerning the specifications we utilise to look at the data, we also consider the contributions on leaning against the wind policies (LAW, see as a general reference Svensson $(2017 a, b))$, although this avenue is out of the scope of this work.

The inclusion of financial variables in the monetary policy rule is motivated on one hand by the leaning against the wind policies: in this framework Central Banks reacts to excessive risk-taking and deflate bubbles before their bust, and symmetrically revive languishing financial conditions. Svensson $(2017 a, b)$ offers an excellent summary of this literature. On the other hand, we relate to works that analyse official reports and documents to assess whether the Fed takes into account financial factors. Oet and Lyytinen (2017) and Peek, Rosengren, and Tootell (2016) find that discussing financial stability in FOMC meetings affects policy decisions, Wischnewsky, Jansen, and Neuenkirch (2019) reinforce this evidence analysing congressional hearings of Fed Chairmen. We restrict our focus to liquidity factors because QE injections addressed this specific issue through bal- 
ance sheet expansions. To capture this effect, we proxy liquidity in financial markets with two spreads. The first one is the difference between the Standard \& Poor 500 quarterly returns and the 3-month Treasury Bill, the second is the gap between the average yield of BAA corporate bonds ${ }^{1}$ and the US 10-year Treasury note. These two spreads capture the liquidity premium between safe and totally liquid assets and risky, less liquid ones.

Section 2 presents the dataset we compile and ; Section 3 presents the specifications we estimate, with results for the full sample analysis and the exogenous subsampling ones; Section 4 presents stability tests on the specifications that motivate a Markov Switching model estimation. Section 5 concludes the paper.

\section{Data}

To investigate the US monetary policy conduct, we build a database of the most relevant time series on the US economy aggregates. It includes historical and real time data at the macroeconomic level, as well as statistics from specific microeconomic data to account for expectations. At a broad level, we collect data on inflation, interest rates, ${ }^{2}$ real output slack, monetary aggregates, government debt and deficit, financial market indicators, and finally (measures of) expectations of these variables.

US Taylor rule - main components

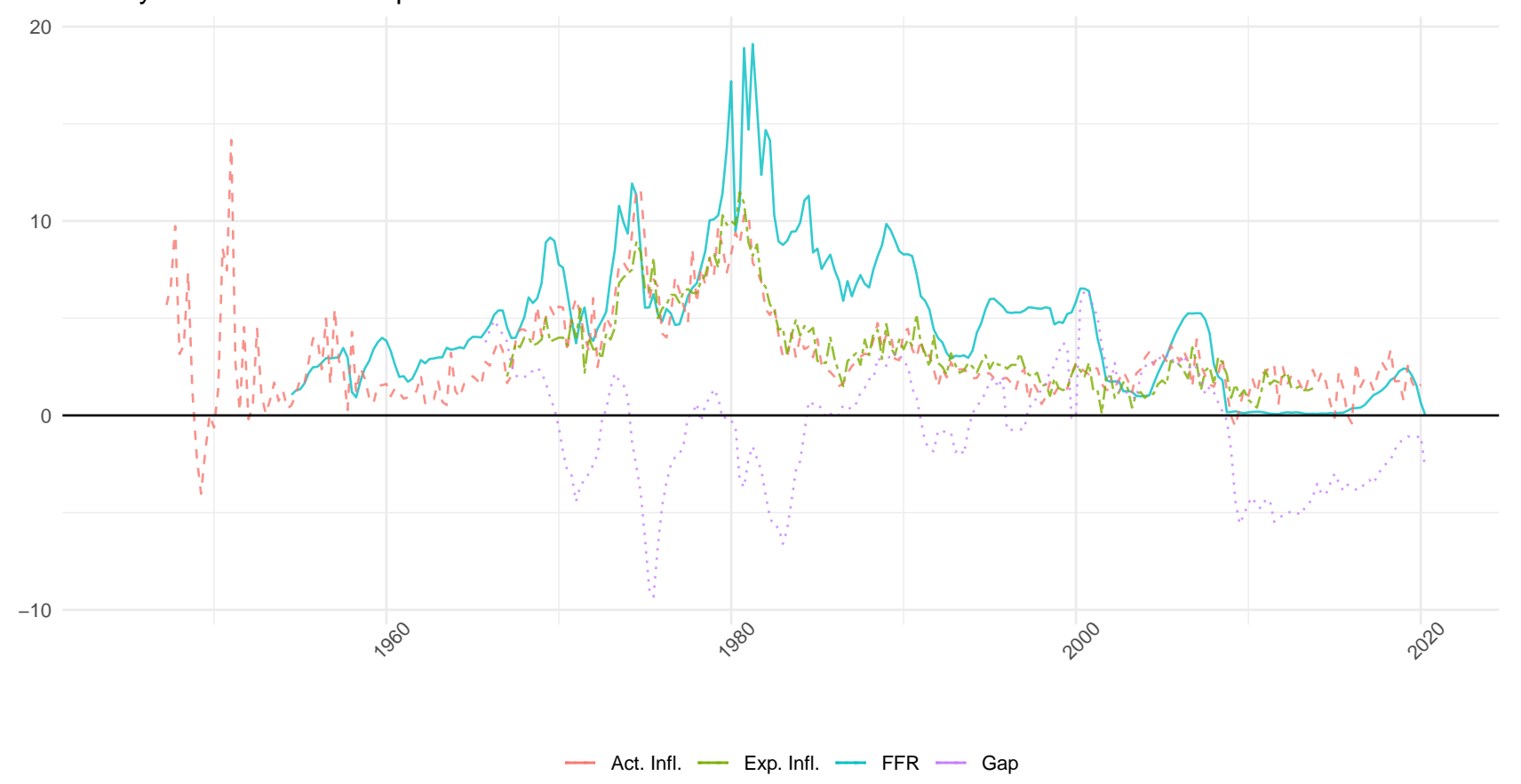

Figure 1: VARIABles EMPLOYED IN THE estimates. HistoricAlly REVISED GDP DEFLATOR (ACT. INFL., DASHED); GREENBOOK ONE-QUARTER GDP DEFLATOR FORECAST (EXP. INFL., DOT-DASHED); FEDERAL FUND RATE (FFR, SOLID); GREENBOOK ESTIMATED OUTPUT GAP (GAP, DOTTED).

For each one of these aggregates, we collect a set of more specific measures that differ

\footnotetext{
${ }^{1}$ This series is provided by Moody's.

${ }^{2}$ We also include $\mathrm{Wu}$ and Xia (2016) shadow rate for the FFR, although it is not used in the work as it does not add any further insight.
} 
in the exact definition or computation: the clearest examples are the GDP deflator, the $\mathrm{CPI}$, and the CPE for inflation, or the capacity utilization, lay-off rate, unemployment, and Fed's own calculations for the output gap. A side contribution of this paper is to provide a collected database as well as the tools to maintain, fine-tune, and customize it.

We also source microdata from the Greenbook dataset on forecasts and expectations, as well as the University of Michigan Survey of Consumers. The former includes the Survey of the Professional Forecasters, which provides expectations on economic aggregates at several time horizons. The financial information we employ relies on two measures: the quarterly returns of the S\&P 500 index and the weighted average return of BAA corporate bonds. These series are then treated and used as proxies for the liquidity in the economy.

The vast majority of the series are retrieved from the Federal Reserves of St. Louis and Philadelphia: a complete list is provided in the Appendix, Table (9). ${ }^{3}$

For a subset of the data we performed some transformations and manipulations to isolate precise information. We briefly introduce the transformed data below.

Output gap We included several different measures of output slack, among which two are worth detailing. First, official output gap nowcast. This extrapolation uses data from the Greenbook database on the real time estimates on the GDP level and implements the methodology mentioned in Murray, Nikolsko-Rzhevskyy, and Papell (2015). For each available date $t$, we regress the time series against a quadratic time trend and finally take the residual of the latest available data point, $\varepsilon_{t}$, as output gap observation for date $t$. We label the resulting time series as real time output gap. ${ }^{4}$ It is closer to the signal policymakers receive at the time of the decision.

Second, we compute the percentage difference between installed capacity and actual GDP, both provided by St. Louis Fed. We call this series ex post output gap since it relies on historical, revised data, not necessarily those available to policy makers at the time of their contingent decisions.

All measures are intended to encompass the advances in the related literature, including contributions due to Benhabib, Schmitt-Grohe, and Uribe (2001), Bilbiie and Straub (2013), Boivin (2006), Cochrane (2011), Gali and Gertler (1999), Gali, Gertler, and LopezSalido (2001), and Orphanides $(2001,2004)$.

Inflation and expectations Concerning the measures of inflation, we include revised time series like the indexes of GDP deflator, the Consumer Price Index (CPI), and the Personal Consumption Expenditure (PCE). For the last two, we also include two reduced versions that exclude food and energy prices, dubbed Core CPI and PCELFE.

The Greenbook database from the Philadelphia Fed provides information on last, current and expected future values for three of the aforementioned indexes, namely CPI, Core $\mathrm{CPI}$, and GDP deflator. In particular, forecasts are available up to eight quarters ahead from time $t$. The same database also offers nowcasts on current and last value of these variables. These expectations are part of the information set of the policy-maker at the time of decision and thus represent a reliable tool to gauge the policy rule.

\footnotetext{
${ }^{3}$ The resulting dataset, as well as the code to compile and maintain it, are available in this Git repository. The code itself might undergo significant improvement and extension over time.

${ }^{4}$ Further details are presented in the Data Appendix (B.1).
} 
Liquidity proxies: financial indexes After the financial markets collapse that triggered the Global Financial Crisis in 2008, liquidity in the economy gained momentum as research topic (alongside with safe assets and thus risk) especially following the massive injections carried out by the Federal Reserve, see among others Caballero, Farhi, and Gourinchas (2016, 2017), M. B. Canzoneri and B. T. Diba (2005), M. Canzoneri et al. (2008a,b), Del Negro et al. (2017), and Hall and Reis (2016).

We employ the financial condition of the economy to parse out information on its liquidity. Financial market prices embody plenty of different information, so the risk of picking up the wrong signal or incur in plain endogeneity is high. Considering these threats we compute our indicators as premia over safe assets of comparable maturity, which are subject to "fire-purchases" in times of uncertainty or economic turmoil.

The simple intuition goes as follows: on the edge of a recession or slowdown, publicly traded assets are fully liquid ${ }^{5}$ and smoothly traded; when uncertainty kicks in or expectations turn pessimistic, these assets become second choice to more reliable, safer assets. Therefore, the spread between the former and the latter factors in the variation in liquidity of the the economy.

We include these spreads in the decision rule of the Central Bank in order to test whether policy makers are also attentive to the liquidity in the economy and act accordingly. In a sense, these specifications might report biased results when the Central Bank resorts to unconventional monetary policy tools. The main threat comes in particular from forward guidance announcements that substantially affect the financial market. To this end, we control for equivalent maturity Treasuries yields to isolate liquidity factors.

Throughout the rest of the paper we use the GDP deflator as measure of inflation, since it maps closely the price dynamics emerging from the US economy. Moreover, its time series is the longest and affords estimation in the pre-Volcker period. To reproduce the information set of the Fed, we use our real time output gap measure. Both series strongly correlate with the alternatives and bear little differences in trends.

For completeness, Table (11) in the Appendix presents correlations among selected variables in our dataset over the period 1986Q1:2013Q4, when all series overlap.

\section{Empirical results}

In the literature there is a broad consensus on the empirical validity of the Taylor rule at least since the chairmanship of Volcker. Volcker, the consensus goes, induced a switch in policy from a regime of indeterminacy (accommodation policy) to one of determinacy. One of the first attempts to verify such break in policy is Clarida, Gali, and Gertler (2000), who exogenously divide their sample in two periods according to chairmanship and obtain estimates for each subsample. They find that the Fed was following a passive monetary policy during the first part of the sample, whereas an active policy emerged after Volcker chairmanship, engineering the ensuing stable inflation path over the following decades.

\footnotetext{
${ }^{5}$ A narrow ask/bid gap.
} 
By contrast, Boivin (2006) uses a different approach and lets the real time data speak, estimating a Taylor rule with drifting parameters over the sample. He finds that inflation response was weak in the second half of the 1970s, but strong in the rest of the sample. The response to real activity, measured as the deviation of the unemployment from its natural rate, decreased significantly and permanently after the 1970s. Starting from the mid-1980s, he finds that stability in the policy parameters increased. These changes happened in an unsynchronised way, with the most important changes occurring between 1980 and 1982, the transition years of Volcker chairmanship. In the same vein, Primiceri (2005) employs a Bayesian SVAR to estimate how the Fed reacted dynamically to inflation and unemployment, finding that it complies to the Taylor Principle even prior to Volcker.

Another approach to endogenise policy changes is proposed in Murray, Nikolsko-Rzhevskyy, and Papell (2015), where Hamilton (1989) algorithm for Markov processes estimation is applied to monetary policy rules. They explore the two-state case, finding two periods of undetermined policy, precisely 1973:1975 and 1979:1985, again in coincidence of the transition period before inflation was "conquered." The point estimates from Clarida, Gali, and Gertler (2000) and Murray, Nikolsko-Rzhevskyy, and Papell (2015) are summarized in the tables below.

\begin{tabular}{|c|cccc|}
\hline Exogenous break & $\mu$ & $\gamma$ & $\omega$ & $\rho$ \\
\hline \multirow{2}{*}{ Pre - Volcker } & 4.24 & -.17 & .27 & .68 \\
& $(1.09)$ & $(.07)$ & $(.08)$ & $(.05)$ \\
Post - Volcker & 3.58 & 1.15 & .93 & .79 \\
& $(.5)$ & $(.4)$ & $(.42)$ & $(.04)$ \\
\hline
\end{tabular}

TABle 1: Clarida, GAli, AND Gertler (2000)

\begin{tabular}{|c|cccc|}
\hline Markov State & $\mu$ & $\gamma$ & $\omega$ & $\rho$ \\
\hline \multirow{2}{*}{$S_{1}$} & 9.44 & -.3 & .46 & .49 \\
& $(3.07)$ & $(.34)$ & $(.26)$ & $(.15)$ \\
$S_{2}$ & .59 & .85 & .58 & .8 \\
& $(.66)$ & $(.23)$ & $(.09)$ & $(.05)$ \\
\hline
\end{tabular}

TAble 2: Murray, NiKolsko-RZheVskyy, AND PAPEll (2015)

Motivated by these results, we study the stability of the parameters of the Taylor rule in the post-WWII period. We propose a set of estimates of the decision rule followed by the monetary authority. After analysing the full sample with OLS estimators ${ }^{6}$, we exogenously split the sample in three sub-samples and compare the parameters. Then, we investigate possible structural breaks over the full sample via stability diagnosis. Third, we let the sub-sampling be endogenous with a Markov Switching estimation for two possible states.

\subsection{Specifications}

We assess the robustness of the traditional specification in comparison to the alternatives with liquidity proxies. Our interest lies particularly in the parameters stability over dif-

\footnotetext{
${ }^{6}$ Carvalho, Nechio, and Tristao (2018) provide motivation for using OLS in estimating monetary policy rules and quantify the bias of such method compared to GMM or IV.
} 
ferent methods, sample cuts, and when we include financial conditions in the information set.

Throughout this Section, we will estimate equation (1): $r$ is the effective federal fund rate, $\pi_{t+h}$ is $h$-period ahead expected inflation (mapped to forecasts, up to 8-quarter), $\hat{y}$ is output gap in percentage deviation, and $X$ collects any additional variables used in the study, as detailed in Section (2).

$$
r_{t}=(1-\rho)\left[\mu+(1+\gamma) E_{t} \pi_{t+h}+\omega \hat{y}_{t}+\boldsymbol{X}_{t}^{\prime} \boldsymbol{\beta}\right]+\rho r_{t-1}+\varepsilon_{t}
$$

In equation (1), we assume that the Central Bank smooths its policy decision putting a weight $0<\rho<1$ on past interest rate level. Therefore, we need to recover estimates and confidence intervals from the estimated $\rho$. Moreover, we allow for inflation targeting including an intercept $\mu$. $\varepsilon_{t}$ captures the exogenous shock the monetary authority impulses to the rate path.

We focus our attention on a subset of parameters, $\beta_{i}$ and $\gamma$. The sign and the magnitude of the former will tell how relevant other factors are for the Central Bank; on the other hand, $\gamma$ will shed light on the robustness of the Taylor Principle. Established consensus points to a value close to $\gamma=.8$ following the onset of the Great Moderation and the inflation conquest carried out by Volcker.

Before exposing the results, we precise the specifications we estimate throughout this Section and briefly motivate their utilization. We select and present these specifications because other combinations, although conceptually appealing, do not necessarily add interesting insights or fall outside the scope of this work.

Spec. I $r_{t}=(1-\rho)\left[\mu+(1+\gamma) E_{t} \pi_{t+1}+\omega \hat{y}_{t}\right]+\rho r_{t-1}+\varepsilon_{t}$ : the standard specification as in Taylor (1993) and many other works. We employ one period ahead forecasts of GDP deflator as expected inflation and real-time gap for output slack. Considerably, we employ uniquely real time data so to track as closely as possible the information set available to the Central Bank.

Spec. II $r_{t}=(1-\rho)\left[\mu+(1+\gamma) E_{t} \pi_{t+1}+\omega \hat{y}_{t}+\beta \mathrm{BAA}_{t}\right]+\rho r_{t-1}+\varepsilon_{t}$ : we introduce in this specification a proxy for financial distress, namely the spread between BAA corporate bonds and 10 years Treasury bonds.

Spec. III $r_{t}=(1-\rho)\left[\mu+(1+\gamma) E_{t} \pi_{t+1}+\omega \hat{y}_{t}+\beta S \& P 500_{t}\right]+\rho r_{t-1}+\varepsilon_{t}$ : we test a second proxy for liquidity with this specification. We exploit quarterly returns on the stock market to obtain a spread with 3-month Treasury Bills. In this case we want to avoid the possible influence of default risk present in bonds yields.

Specifications I is a traditional formulation of the Taylor rule, Spec. II and III embed financial condition proxies.

\subsection{Full sample analysis}

The first step is to estimate our specifications on the full sample, overlooking the possibility of structural breaks or fluctuations in the parameters. The period covered varies with the series included in the specification, from a maximal of about 185 observations to a minimum of slightly less than $115 .^{7}$ Such approach simply yields an average of the estimated

\footnotetext{
${ }^{7}$ Greenbook real time data, in particular, are released to the public with a 5-year lag with respect to the estimates or forecasts and thus presents data until 2014. Moreover, data on BAA spreads are available only from 1986Q1.
} 
parameters over the set of possible subsamples. Assuming parameter instability of any form and correct specification, this approach produces simple averages over the possible parameter values. In this sense, regimes that are more frequently in place will be more represented in the final estimate. Table (3) summarises the results of OLS estimates on the full length sample for the different specifications.

\begin{tabular}{|c|c|c|c|}
\hline \multirow{2}{*}{ Var. } & \multicolumn{3}{|c|}{ Specification } \\
\hline & $\mathrm{I}$ & II & III \\
\hline \multirow[b]{2}{*}{$\mu$} & .1327 & $8.1884^{* * *}$ & .3355 \\
\hline & $(.7766)$ & (1.6854) & $(.5268)$ \\
\hline \multirow{2}{*}{$E_{t}(\mathrm{GDP} \text { defl. })_{t+1}$} & $1.5811^{* * *}$ & $.9522^{*}$ & $.9528^{* * *}$ \\
\hline & $(.2736)$ & (.4673) & (.1883) \\
\hline \multirow{2}{*}{ Real time $\hat{y}$} & $.48^{* *}$ & $.2496^{+}$ & $.2361^{*}$ \\
\hline & (.1439) & (.1437) & (.0998) \\
\hline BAAspr. & \multicolumn{3}{|c|}{$\begin{array}{c}-2.9673^{* * *} \\
(.4939)\end{array}$} \\
\hline SPspr. & & & $\begin{array}{c}-.4349^{* * *} \\
(.0951)\end{array}$ \\
\hline$F F R_{t-1}$ & $.7782^{* * *}$ & $.8643^{* * *}$ & $.6877^{* * *}$ \\
\hline & $(.0369)$ & $(.0289)$ & $(.0402)$ \\
\hline Obs. & 188 & 112 & 188 \\
\hline$R^{2}$ & .8949 & .9733 & .9052 \\
\hline$B I C$ & 628 & 157 & 612 \\
\hline
\end{tabular}

TABle 3: OLS ESTIMATES IN THE FULl SAMPLE, UP TO 2013 Q2. SignificANCE CODES: 0 '***' $0.001^{\prime} * *^{\prime} 0.01^{\prime} *^{\prime} 0.05^{\prime}+^{\prime} 0.1$; SE IN PARENTHESES.

These results are interesting in a number of aspects. First, the sample encompasses a variety of regimes: from the pre-Volcker era to the ZLB period, with the Great Moderation dwarfing other regimes in terms of observations. Therefore, it blends together different rules and behaviours with diverse weights.

Second, the addition of liquidity in the policy rule of the Central Bank marks a consistent violation of the Taylor Principle, with $\gamma$ estimates below 1 for Specifications II and III. The inclusion of liquidity proxies significantly lowers the weight on inflation expectations. This finding is even more surprising when considering that the BAA spread series starts in 1986Q1, at the end of Volcker's mandate. These results suggest that financial conditions enter the decision set of the Central Bank with the expected sign.

As mentioned before, the length of the sample blends multiple regimes and stances. In this light it is not surprising to find substantial parameters instability, as Table (3) presents. Under the hypothesis of $\mu$ as inflation target, its estimates greatly vary according to the sample and the specification. The same, with less variability, applies for $\omega$ and $\rho$, the smoothing factor. To address this issue, we split the sample in three sub-samples, upon which we cast the assumption of different regimes. ${ }^{8}$

\footnotetext{
${ }^{8}$ Appendix (B.2) offers the residuals plot for the full sample regression. Eyeballing these plots provides sufficient motives to carry out additional analyses on model instability.
} 


\subsection{Exogenous breaks}

The estimates above might result from a variety of underlying regimes, smooth (Boivin, 2006; Primiceri, 2005) or discrete (Murray, Nikolsko-Rzhevskyy, and Papell, 2015). To account for such regime change, a straightforward approach is to look for relevant historical events that mark a discontinuity and estimate the policy rule before and after such dates. In our framework it corresponds to splitting the sample in three subsamples: post-WWII period, the Great Moderation, and the GFC. The latter in particular encompasses the liquidity injections of the Quantitative Easing in correspondence of the Zero Lower Bound period. This last condition distinguishes the first from the third subsample. In fact, in the postwar period the federal fund rate averaged around $5 \%$, with a minimum value of $.93 \%$ for one quarter only. The downside is that at date this subsample presents a small number of observations, which makes inference rather hard. We split the sample to obtain three phases:

(i) pre-Volcker regime [-:1981Q4],

(ii) the Great Moderation [1982Q1:2007Q2],

(iii) and finally the GFC [2007Q3:-].

Historically, the period covered by sub-sample (i) reports high inflation and federal fund rate, as well as volatile cyclical fluctuations. According to Clarida, Gali, and Gertler (2000), among others, the Fed carried out an accommodative monetary policy in that period, following inflation instead of aggressively responding to its expectations. Hence, we expect to see values close to those presented in Table (1). Unfortunately, data availability limits the estimation of our Spec. II.

The second chunk of data covers the inflation conquest and the miraculously steady and sustained growth that followed, with mild recessions and inflation in check. Supposedly, this conditions were brought about by a Central Bank eventually fighting back inflation aggressively, adjusting the FFR more than one-to-one with respect to expected inflation.

The third period starts right before the GFC. Data are still scarce: to date, we have about 10 years of quarterly data with hardly enough variation, mainly because of the FFR hitting the zero lower bound and hovering in its neighbourhood. Therefore, the estimates here shall be considered cum grano salis.

Skimming through Table (4) it is interesting to compare the regimes in place. Although the heterogeneity in available observations restricts significantly the econometric robustness of such exercise, a number of regularities emerges.

In particular, $\gamma$ estimates post a high volatility, both across and within subsamples. Contrary to the consensus (but in line with Boivin (2006) and Primiceri (2005)), the Fed broadly complied to the Taylor Principle, although Spec. II and III present values statistically close to 0 for $\gamma$. In the second period, in line with the narrative of a committed and credible Central Bank, $\gamma$ complies to the Taylor Principle in all specifications, but present a significant volatility in the estimates. Strikingly, inflation expectations seem to disappear from the relevant set for monetary policymaking, as overall its estimates are not significant.

Likewise, output gap measures seem less relevant in the wake of the GFC than previous periods, when $\omega$ estimates take expected values and signs without much volatility. Implicit inflation target, $\mu$, display an erratic behaviour and provide a less than convincing picture over the periods. 


\begin{tabular}{|c|c|c|c|c|c|c|c|c|c|c|}
\hline Sample & Spec. & $\mu$ & $E_{t}(\text { GDP defl. })_{t+1}$ & Real time $\hat{y}$ & BAA spr. & SP spr. & $F F R_{t-1}$ & Obs. & $R^{2}$ & $B I C$ \\
\hline \multirow{2}{*}{ (i) } & I & $\begin{array}{l}-.2145 \\
(1.6457)\end{array}$ & $\begin{array}{c}1.4885^{* * *} \\
(.362)\end{array}$ & $\begin{array}{l}.5266^{*} \\
(.2207)\end{array}$ & & \multirow[b]{2}{*}{$\begin{array}{c}-.4938^{* * *} \\
(.1131)\end{array}$} & $\begin{array}{c}.5985^{* * *} \\
(.0882)\end{array}$ & 60 & .7664 & 258 \\
\hline & II & $\begin{array}{l}.1106 \\
(.9632)\end{array}$ & $\begin{array}{c}.8069^{* * *} \\
(.216)\end{array}$ & $\begin{array}{l}.2226^{+} \\
(.1324)\end{array}$ & & & $\begin{array}{c}.4022^{* * *} \\
(.0889)\end{array}$ & 60 & .8234 & 244 \\
\hline \multirow{3}{*}{ (ii) } & I & $\begin{array}{l}-.7987 \\
(1.4227)\end{array}$ & $\begin{array}{c}2.1619^{* *} \\
(.6898)\end{array}$ & $\begin{array}{l}.3646^{+} \\
(.2179)\end{array}$ & \multirow{3}{*}{$\begin{array}{c}-4.215^{* * *} \\
(.7594)\end{array}$} & & $\begin{array}{c}.8495^{* * *} \\
(.0404)\end{array}$ & 102 & .9352 & 238 \\
\hline & II & $\begin{array}{c}9.79^{* * *} \\
(2.18)\end{array}$ & $\begin{array}{c}1.1145^{*} \\
(.5147)\end{array}$ & $\begin{array}{c}.6558^{* *} \\
(.2027)\end{array}$ & & & $\begin{array}{c}.8642^{* * *} \\
(.0299)\end{array}$ & 86 & .9606 & 120 \\
\hline & III & $\begin{array}{c}-.2352 \\
(.9721)\end{array}$ & $\begin{array}{c}1.4082^{* *} \\
(.4705)\end{array}$ & $\begin{array}{l}.1749 \\
(.1503)\end{array}$ & & $\begin{array}{c}-.3954^{* *} \\
(.1188)\end{array}$ & $\begin{array}{c}.7892^{* * *} \\
(.0425)\end{array}$ & 102 & .9413 & 232 \\
\hline \multirow{3}{*}{ (iii) } & I & $\begin{array}{c}-48.64^{+} \\
(26.01)\end{array}$ & $\begin{array}{c}3.6837 \\
(8.22)\end{array}$ & $\begin{array}{c}-8.984^{+} \\
(4.37)\end{array}$ & \multirow{3}{*}{$\begin{array}{c}-1.1005^{*} \\
(.4948)\end{array}$} & & $\begin{array}{c}.9846^{* * *} \\
(.1015)\end{array}$ & 26 & .9351 & 29 \\
\hline & II & $\begin{array}{c}2.7847 \\
(.347)\end{array}$ & $\begin{array}{l}.1705 \\
(.5859)\end{array}$ & $\begin{array}{l}.0925 \\
(.4117)\end{array}$ & & & $\begin{array}{c}.8004^{* * *} \\
(.1249)\end{array}$ & 26 & .945 & 27 \\
\hline & III & $\begin{array}{c}-10.43 \\
(9.185)\end{array}$ & $\begin{array}{l}1.058 \\
(2.621)\end{array}$ & $\begin{array}{c}-1.662 \\
(1.675)\end{array}$ & & $\begin{array}{l}.7416 \\
(.549)\end{array}$ & $\begin{array}{c}.9526^{* * *} \\
(.1024)\end{array}$ & 26 & .9375 & 30 \\
\hline
\end{tabular}

TABle 4: EXOGENOUS SPLits, THREE SAMPLES. SignifiCANCE CODES: $0{ }^{\prime} * * *^{\prime} 0.001^{\prime} * *^{\prime} 0.01^{\prime} *^{\prime}$ $0.05^{\prime}+{ }^{\prime} 0.1$; SE IN PARENTHESES. (i) RUNS FROM THE EARLIEST AVAILABLE OBSERVATION TO 1981Q4; (ii) RUNS FROM 1981Q4 TO 2007Q2; (iii) GOES FROM 2007Q3 TO THE LATEST OBSERVATION AVAILABLE, CURRENTLY 2013Q2, AS SOME DATA ARE PUBLISHED WITH A FIVE YEARS LAG.

Focusing on cross samples comparison, the BAA spread holds robust estimates over time and across specifications, like the S\&P500 spread, pointing to our intuition that financial conditions are key. When liquidity dries up because of financial or real turmoil (and hence spreads increase) the monetary authority puts in place accommodative policies by decreasing the reference interest rate. On top of that, there is a noticeable increase in the federal fund rate persistence over time. The first subsample present a quite volatile policy rate, whilst subsample (ii) reports significant increases in $\rho$. The most recent subsample, with scarce observations, includes a key policy rate that barely moves, with other variables displaying more variability. This explains why in all regression the most significant variable is the lagged interest rate, while all other variables present odd estimates. Nevertheless, some results are suggestive of fundamental parameters instability, consistently with the Fed switching to QE policies (de facto liquidity injections).

These early results point towards an unstable behaviour of the Central Bank - if we assume its only behaviour takes the form of a strictly parametrised Taylor rule. In particular the great deal of volatility in the estimates across sub samples motivates a deeper investigation in the stability of the parameters. This in turns mirrors a changing policy stance for the monetary authority, as encapsulated by the Taylor rule specifications. The next step, therefore, is to diagnose possible sources of structural breaks or parameter variability and to address these pathologies with proper, flexible tools.

\section{Diagnostics on structural breaks and Markov Switching}

Subsampling according to historical events is an appealing device, but it does not provide a robust statistical motivation. To address this shortcoming, we exploit a number of tests that diagnose the stability of the estimated parameters. Compared to the exogenous sub- 
sampling, this approach is more data driven, as it makes use of the information contained in the sample to check for breaks and eventually propose the most likely break date(s). We run these diagnostics on the full sample to elicit precise dates. Following the established consensus, we expect to find breaks in correspondence of the Volcker chairmanship and the GFC.

To this purpose, we take the models estimated on the full sample and run first a simple CUSUM diagnostic test, then a Chow (1960) test. The latter in particular is flexible enough to provide an optimal segmentation of the sample based on parameters stability. Basing on the Bayes Information Criterion, the Chow test can produce the most likely date of break, provided that we require only one single date; or it can provide the most likely number of breaks in the the sample. We exploit these properties in our analysis.

As straightforward check, CUSUM tests do not report significant fluctuations in the empirical process, meaning that the cumulative sum of the residuals eventually levels off to 0 without significant erratic deviations. It is nevertheless interesting to remark how persistent over time the deviations are and how consistently the CUSUM statistics builds up towards the end of the sample. Plots of this diagnostic are presented in the Appendix (B.3). The F-Test derived from Chow (1960) points in another direction, though. The output of the test actually reports multiple breaks along the sample, some of which occur with unexpected timing.

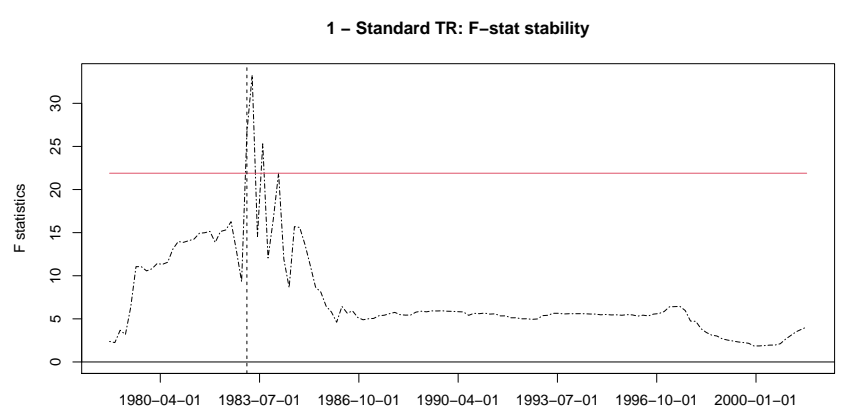

Vertical line indicates date of mime ${ }^{\text {mint }}$ likely break: 1980-07-01

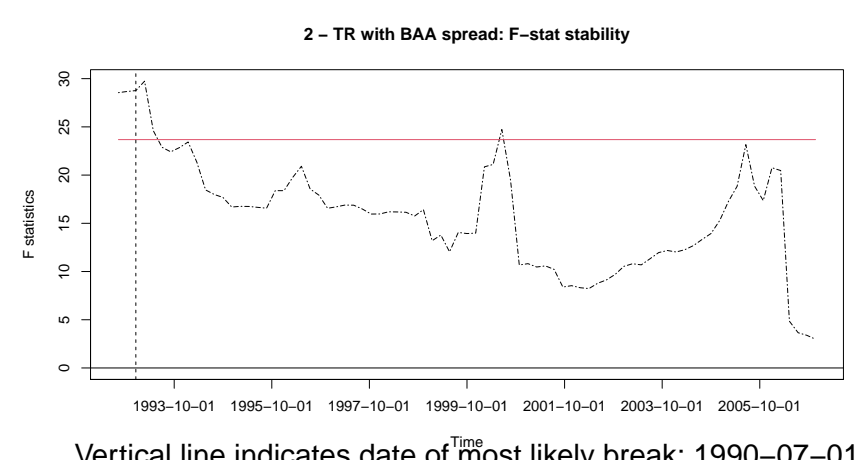

Vertical line indicates date of ${ }^{\text {Time }}$ most likely break: 1990-07-01

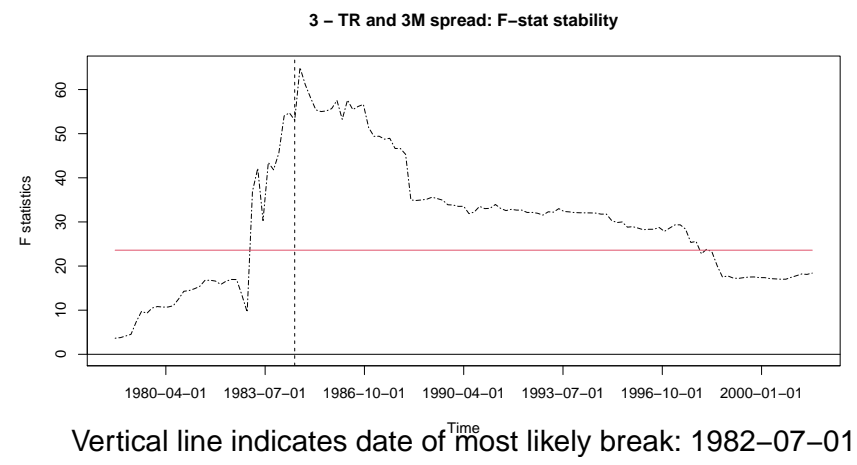

Figure 2: F-STATISTIC PLOTS FOR SPECIFICATIONS I TO VIII. DASHED LINE INDICATES THE STATISTICS VALUE, SOLID HORIZONTAL LINE MARKS THE SIGNIFICANCE AREA AT 95\%. INDIVIDUAL CAPTIONS OFFERS MOST LIKELY DATE FOR A singular STRUCTURAL BREAK IN THE SPECIFICATION POINTED BY THE VERTICAL DASHED LINE.

When only the most likely date break is requested, two out of three specifications report it around two years into Volcker's Chairmanship (specifications I and III, involving BAA spread, which start in 1986), decidedly in line with the established consensus. What is 
more interesting is the picture depicted by Fig. (2): these specifications, especially those including the 3-month spread variable, report F-statistics hovering above the threshold for well more than one observation. The results of optimal segmentation of the sample pave the way to the Markov switching estimation below as it motivates further inquiry into the existence of multiple policy regimes.

TABLE 5

\begin{tabular}{|c|c|c|c|}
\hline & \multicolumn{3}{|c|}{ Specification } \\
\cline { 2 - 4 } & I & II & III \\
\hline Sing. break & 1980Q3 & 1990Q3 & 1982Q3 \\
N. of breaks & 2 & 3 & 2 \\
Date 1 & 1980Q3 & 1989Q4 & 1980Q3 \\
Date 2 & 1987Q3 & 2000Q4 & 1987Q3 \\
Date 3 & - & 2008Q3 & - \\
\hline
\end{tabular}

TABLE 6: OPTIMAL SEGMENTATION AND BREAK DATES: FIRST ROW PRESENTS THE MOST LIKELY BREAK ADMITTING ONLY A SINGLE ONE. THIRD TO FIFTH ROWS PRESENT BREAK DATES WHEN UP TO 5 BREAKS ARE ALLOWED.

Table (6) summarises the analysis on optimal segmentation. It highlights, also, that most of the specifications likely involve more than one structural break. On top of Volcker's regime change, one would reasonably expect that the mix of ZLB and unconventional policies would be sufficient to mark an additional break. Moreover, a striking result is that in two cases (specifications I and III) the end of Volcker's two terms is also a candidate point for a strctural discontinuity. ${ }^{9}$ These results suggest that there has been a structural break when Volcker left the Chair, with Greenspan chairmanship introducing an additional new regime. Hence, there might be one or more than one discrete regimes of monetary policy, among which the Federal Reserve switches back and forth. Therefore, it is clearly worth pursuing additional insights into these structural breaks with adequate techniques.

\subsection{Markov Switching estimation}

We further unconstrain the data via a Markov Switching model: we adopt Hamilton (1989, 1994) and Murray, Nikolsko-Rzhevskyy, and Papell (2015) approach to our extended sample and only assume it comprises $k$ discrete states. We restrict our analysis to $k=2$, in line with the discussion on the determinacy or indeterminacy regimes at the beginning and at the end of our sample. As aforementioned, pre-Volcker and post-GFC periods yield deeper insight on the functioning of the Federal Reserve monetary policy conduct away from the Great Moderation "steady state."

$$
\begin{aligned}
r_{t}= & \left(1-\rho^{S}\right)\left[\mu^{S}+\left(1+\gamma^{S}\right) E_{t} \pi_{t+h}+\omega^{S} \hat{y}_{t}+X_{t}^{\prime} \beta^{S}\right]+\rho^{S} r_{t-1}+\varepsilon_{t}^{S} \\
& \operatorname{var}\left(\varepsilon_{t}^{S}\right)=\sigma^{S} \quad \text { with } \quad S=k \in\{1, \ldots, K\}
\end{aligned}
$$

Hamilton (1989) provides the algorithm to estimate our specifications with $k$ states, generating also transition matrices and smoothed probabilities to pick the prevailing regime in

\footnotetext{
${ }^{9}$ Volcker was nominated July $25^{\text {th }}, 1979$, sworn shortly after August $6^{\text {th }}$, and left the Chair in August $11^{\text {th }}, 1987$. In our quarterly dataset it translates in 1979Q3:1987Q3.
} 


\begin{tabular}{|c|c|c|c|c|c|c|c|c|c|}
\hline Spec. & State & $\mu$ & $E_{t}(\mathrm{GDP} \text { defl. })_{t+1}$ & Real time $\hat{y}$ & BAA spr. & SP spr. & $F F R_{t-1}$ & Adj.R $R^{2}$ & $B I C$ \\
\hline \multirow{3}{*}{ I } & $S_{1}$ & $\begin{array}{c}-.7759 \\
(2.025)\end{array}$ & $\begin{array}{c}1.693^{* * *} \\
(.4816)\end{array}$ & $\begin{array}{l}.3554 \\
(.329)\end{array}$ & & & $\begin{array}{c}.6128^{* * *} \\
(.1118)\end{array}$ & .7853 & \multirow{3}{*}{518} \\
\hline & $S_{2}$ & -.4052 & $2.012^{* * *}$ & $.6329^{* *}$ & & & $.9208^{* * *}$ & & \\
\hline & $\mathrm{S}_{2}$ & $(1.199)$ & $(.4131)$ & $(.2274)$ & & & $(.0253)$ & & \\
\hline \multirow{3}{*}{ II } & $S_{1}$ & $\begin{array}{c}2.74^{*} \\
(-)\end{array}$ & $\begin{array}{c}-.7505^{+} \\
(-)\end{array}$ & $\begin{array}{c}.0564 \\
(-)\end{array}$ & $\begin{array}{c}-.3956 \\
(-)\end{array}$ & & $1.099^{* * *}$ & -9987 & \multirow{3}{*}{142} \\
\hline & $S_{2}$ & $11.01^{* * *}$ & .3199 & $.442^{* *}$ & $-4.066^{* * *}$ & & $.8385^{* * *}$ & & \\
\hline & $\mathrm{S}_{2}$ & $(1.264)$ & (.3338) & (.1367) & (.3692) & & $(.0234)$ & & \\
\hline \multirow{2}{*}{ III } & $S_{1}$ & $\begin{array}{c}1.45 \\
(1.322)\end{array}$ & $\begin{array}{c}.5299^{* * *} \\
(.1596)\end{array}$ & $\begin{array}{c}-.2855^{+} \\
(.1458)\end{array}$ & & $\begin{array}{c}-.6061^{* * *} \\
(.0938)\end{array}$ & $\begin{array}{c}-.0642 \\
(.1416)\end{array}$ & .8505 & \multirow{2}{*}{518} \\
\hline & $S_{2}$ & $\begin{array}{r}-.8855 \\
(.9915)\end{array}$ & $\begin{array}{c}1.561^{* * *} \\
(.3917)\end{array}$ & $\begin{array}{l}.4535^{*} \\
.2005)\end{array}$ & & $\begin{array}{c}-.2201 \\
(.1712)\end{array}$ & $\begin{array}{c}.8982^{* * *} \\
(.0286)\end{array}$ & .9623 & \\
\hline
\end{tabular}

TABle 7: Estimates FOR $k=2$ MARKOV SWITCHING MODEL. SignificANCE CODES: $0^{\prime} * * *^{\prime}$ $0.001^{\prime} * *^{\prime} 0.01^{\prime} *^{\prime} 0.05^{\prime}+^{\prime} 0.1$; SE IN PARENTHESES. (-) STANDS FOR NON-CONVERTIBLE SE: SIGNIFICANCE IS HENCE DERIVED FROM THE MAIN REGRESSION.

any date $t$. For every specification, we allow for the variation of every parameter and the variance: in $k$ different states, all parameters are freely estimated, with no constraint posed by other states' estimates. ${ }^{10}$

Table (7) presents estimates for the two state Markov switching model. In contrast to the results of Murray, Nikolsko-Rzhevskyy, and Papell (2015), Specification I - mirroring those of the cited work - finds two states complying to the Taylor Principle. ${ }^{11}$ This tradi- $^{-}$ tional Taylor rule presents two distinct states that differ in terms of reaction intensity. $S_{2}$ estimates present larger coefficients in absolute values for virtually all variables. Focusing on $\gamma$ estimates, both states comply to the Taylor principle, pointing towards a more aggressive reaction in the second state. This evidence does not align with the established consensus, but rather corroborate Orphanides $(2001,2004)$ findings. Interestingly, $S_{1}$ is more likely to be in place during downturns, with a lower persistence of the policy rate. This last piece of evidence suggests that the Fed might react asymmetrically to evolving economic conditions: rapidly in light of downturns, cautiously when the recovery materializes. With respect to the timing, it appear to precede economic turmoil periods: it covers roughly the years of the oil shock, the high inflation that followed, the dot-com crash, and the early stages of the GFC. It is suggestive to connect this regime with a cautious approach of the Federal Reserve: as soon as slowdown factors build up, the policy intervention intensity need to adjust accordingly. On the contrary, when risk, uncertainty, and sources of slowdown are a weak threat, the Central Bank acts with decision to steer the economy.

Turning to the financial specifications (II and III), the picture is less clear. Estimates for $\gamma$ display both regimes of determinacy and indeterminacy. Across these two specifications estimates for the weight of the spread are rather consistent with previous results: to a higher relevance of the financial condition corresponds a lower reaction to expected inflation and real activity (summarized in $S_{1}$ for both Specifications), putting in place an accommodative policy regime. Again, the interest rate persistence is lower in the undeter-

\footnotetext{
${ }^{10}$ Alternatively, a subset of parameters can be optionally estimated across all regimes, so its estimate is invariant to the prevailing regime.

${ }^{11}$ Most likely this discrepancy arises from our longer sample and slightly different method employed in the estimation.
} 
mined regime. The prevailing period for the accommodative monetary policy corresponds roughly to the first Volcker term and the first half of the 1970s: this evidence is at odds with the established narrative that sees Volcker to put swiftly in place an aggressive regime to tame inflation. Looking at the time dimension of these regimes, the picture is complementary to the one drawn from the traditional Taylor rule. In both cases, the indeterminate regime is in place at times of economic and financial distress. One difference is worth noting: in Specification III the ZLB period is described by an active monetary policy regime, while the opposite is found for Spec. II. This difference depends on the fact that bonds are more exposed to the liquidity risk, as well as incorporate a quantity of default risk. This latter factor is less present in the most capitalized companies on the financial market ${ }^{12}$ and might drive the result.

The panels collected in Fig. (3) depict the prevailing state along the sample for the estimates of Table (7). We also propose the transition matrices for the two estimated states. In general, every state appear to be rather sticky: virtually all states will persist to the following period with a probability greater than .8 .

\begin{tabular}{|l|l|l|}
\hline Spec.I & $S_{1}$ & $S_{2}$ \\
\hline$S_{1}$ & .945 & .171 \\
$S_{2}$ & .055 & .829 \\
\hline \hline Spec.II & $S_{1}$ & $S_{2}$ \\
\hline$S_{1}$ & .9086 & .2399 \\
$S_{2}$ & .0914 & .7601 \\
\hline \hline Spec.III & $S_{1}$ & $S_{2}$ \\
\hline$S_{1}$ & .8451 & .0511 \\
$S_{2}$ & .1549 & .9489 \\
\hline
\end{tabular}

TABLE 8: TRANSITION MATRICES: TRANSITION PROBABILITIES FOR TWO-STATE MARKOV PROCEss. Columns ARE CURRENT STATE, HENCE CONDitional ON IT NEXT STATE IS ONE OF THE ROWS.

This collection of evidences points towards a fundamental instability in parameters of the Taylor rule. Moreover, we retrieved periods with - theoretically - destabilising monetary rules and inflation under control at the same time, once liquidity is included in the decision set of the monetary authority. These results suggests that the Taylor Principle might not play a fundamental role in anchoring the inflation expectations: agents could - and did, according to our findings - form expectations about the future paths of prices that are non-degenerate even when the Central Bank deviates from the prescriptions of the New Keynesian workhorse. Other factors are therefore at play in anchoring inflation expectations: while the influence of Central Bank actions remains relevant for the determination of the inflation behaviour, the Taylor Principle appear to be less than granitic.

In our battery of proposed specifications for the monetary rules, proxies for liquidity and for financial conditions have a sizeable and robust role across different methodologies. As soon as liquidity dries up, financial conditions worsen, or uncertainty builds up, the Federal Reserve Bank acts and reacts lowering the reference rate. This finding is consequential since these violations of the Taylor Principle are not accompanied by degenerate behaviour of inflation, at least in the most recent cases.

\footnotetext{
${ }^{12}$ While it is true that during the GFC some systemic banks underwent actual bailouts, it is disputable for the rest of the companies listed in the S\&P 500 .
} 

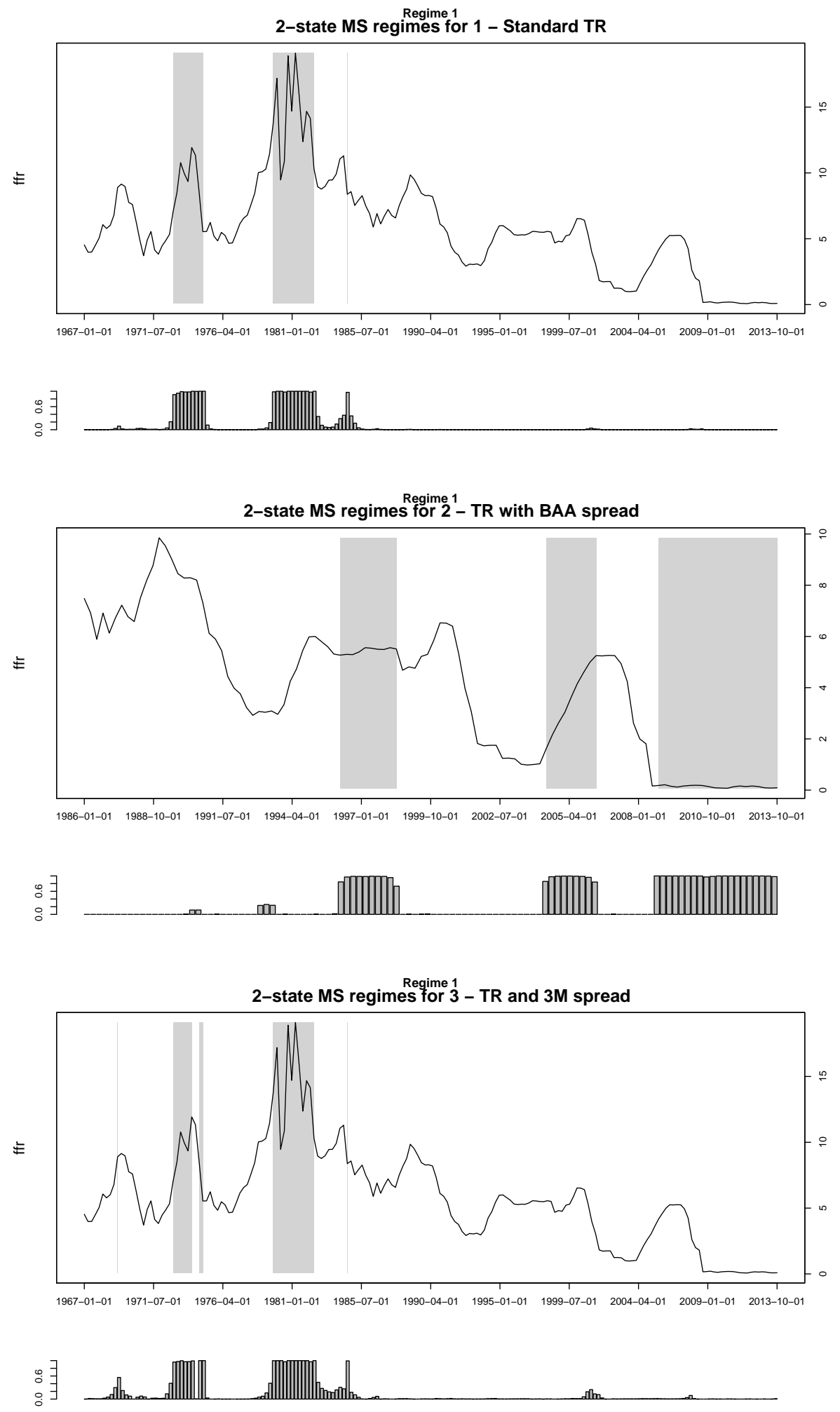

Figure 3: MARKov States: Above Shaded AREAS Correspond to $S_{1}$ PREVAiling OVer $S_{2}$, BELOW SMOOTHED PROBABILITIES FOR $S_{1}$. 


\section{Conclusion}

In this paper we collect and aggregate an important number of data on the US economy, both in real time and revised series. Moreover, we also provide a flexible and easy to tune database including granular information on expectations and now-/forecasts, from policymakers and economic agents. We use this extensive database to empirically investigate the stability of the monetary policy rule in the US postwar period and to test whether the Federal Reserve Bank considers financial markets liquidity in its policymaking.

Using a wide variety of econometric techniques, we study the robustness of the standard Taylor rule required in modern NKDSGE models and cast upon the Central Banks behaviour. A standard rule reveal compliance - with varying intensity - of the Fed to the Taylor principle over the whole period considered, contrary to the established consensus. On the other hand, the inclusion of liquidity spreads reveals that the Fed also considers financial conditions in its interest rate setting. This inclusion also implies consistent violations of the Taylor Principle, without ensuing sunspot inflation episodes. We then provide statistical evidence for the presence of structural breaks in the monetary policy rule.

We analyse the existence of multiple monetary policy regimes and investigate the periods in which each state prevails. We find that when considering financial markets liquidity, the Fed react less than one to one to expected inflation in periods of looming economic uncertainty and distress, when it weights more the liquidity conditions in the economy. Conversely, it switches back to a compliant Taylor rule in tranquil times. Our findings challenge the narrative that sees the US Central Bank accommodating expected inflation until Volcker's regime change and shed new light on the functioning of the US monetary authority and its information set.

Across all estimates we also find evidence of parameters instability, whose effects on realised inflation dynamics and other aggregates are yet to be thoroughly analysed.

On top of this parameter instability, we also find that the Taylor Principle, warranting uniqueness and stability in NKDSGE models, is violated when we include measures of financial markets liquidity. Nevertheless, this violation does not bring about degenerate occurrences of sunspot equilibria, with hyper-inflation or deep disinflation episodes. 


\section{References}

Benhabib, Jess, Stephanie Schmitt-Grohe, and Martin Uribe (2001). "The perils of Taylor rules". In: Journal of Economic Theory (cit. on p. 4).

Bernanke, Ben S. (2002). "Asset-price "bubbles" and monetary policy". In: Remarks before the New York Chapter of the National Association for Business Economics (cit. on p. 1).

Bilbiie, Florin O. and Roland Straub (2013). "Asset market participation, monetary policy rules, and the Great Inflation". In: The Review of Economics and Statistics (cit. on p. 4).

Boivin, Jean (2006). "Has US monetary policy changed? Evidence from drifting coefficients and real-time data". In: Journal of Money, Credit and Banking (cit. on pp. 2, 4, 6, 9).

Caballero, Ricardo J., Emmanuel Farhi, and Pierre-Olivier Gourinchas (2016). "Safe Asset Scarcity and Aggregate Demand". In: American Economic Review (cit. on p. 5).

— (2017). “The safe asset shortage conundrum". In: Journal of Economic Perspectives (cit. on p. 5).

Calvo, Guillermo A. (2016). Macroeconomics in times fo liquidity crises: searching for economic essentials (cit. on p. 2).

Canova, Fabio and Luca Sala (2009). "Back to square one: identification issues in DSGE models". In: Journal of Monetary Economics (cit. on p. 2).

Canzoneri, Matthew B. and Behzad T. Diba (2005). "Interest rate rules and price determinacy: the role of transactions services of bonds". In: Journal of Monetary Economics (cit. on p. 5).

Canzoneri, Matthew et al. (2008a). "Monetary aggregates and liquidity in a neowicksellian framework". In: NBER WP 14244 (cit. on p. 5).

- (2008b). "Monetary and fiscal policy coordination when bonds provide transactions services". In: CEPR WP 6814 (cit. on p. 5).

Carvalho, Carlos, Fernanda Nechio, and Tiago Tristao (2018). “Taylor Rule Estimation by OLS". In: Federal Reserve of San Francisco Working Paper Series 2018-11 (cit. on p. 6).

Chow, Gregory C. (1960). "Tests of equality between sets of coefficients in two linear regressions". In: Econometrica (cit. on p. 11).

Clarida, Richard, Jordi Gali, and Mark Gertler (2000). “Monetary policy rules and macroeconomic stability: evidence and some theory". In: Quarterly Journal of Economic (cit. on pp. 2, 5, 6, 9).

Cochrane, John H. (2011). "Determinacy and identification with Taylor rules". In: Journal of Political Economy (cit. on pp. 1,4).

- (2018). "Michelson-Morley, Fisher, and Occam: the radical implications of stable quiet inflation at the zero bound". In: NBER Macroeconomics Annual (cit. on p. 2). 
Davig, Troy and Eric Leeper (2006). "Fluctuating macro policies and the fiscal theory". In: NBER Macroeconomics Annual (cit. on p. 2).

- (2011). "Monetary-fiscal policy interactions and fiscal stimulus". In: European Economic Review (cit. on p. 2).

Del Negro, Marco et al. (2017). "Safety, liquidity, and the natural rate of interest". In: Brookings Papers on Economic Activity (cit. on p. 5).

Diba, Behzad and Olivier Loisel (2017). "Pegging the interest rate on bank reserves". In: WP (cit. on p. 2).

Gali, Jordi (2015). Monetary Policy, Inflation, and the Business Cycle (cit. on p. 1).

Gali, Jordi and Mark Gertler (1999). "Inflation dynamics: a structural econometric analysis". In: Journal of Monetary Economics (cit. on p. 4).

Gali, Jordi, Mark Gertler, and J.David Lopez-Salido (2001). “European inflation dynamics". In: European Economic Review (cit. on p. 4).

Greenspan, Alan (2002). "Economic volatility". In: Remarks at symposium sponsored by the Federal Reserve Bank of Kansas City, Jackson Hole (cit. on p. 1).

Hall, Robert and Ricardo Reis (2016). "Achieving price stability by manipulating the Central Bank's payment on reserves". In: NBER Working Paper (cit. on pp. 2, $5)$.

Hamilton, James D. (1989). "A new approach to the economic analysis of nonstationary time series and the business cycle". In: Econometrica (cit. on pp. 6, 12).

- (1994). Time series analysis (cit. on p. 12).

Murray, Christian J., Alex Nikolsko-Rzhevskyy, and David H. Papell (2015). "Markov switching and the Taylor principle". In: Macroeconomic Dynamics (cit. on pp. 2, $4,6,9,12,13)$.

Oet, Mikhail V. and Kalle Lyytinen (2017). “Does financial stability matter for the Fed in setting US monetary policy?" In: Review of Finance (cit. on p. 2).

Orphanides, Athanasios (2001). "Monetary policy rules based on real-time data". In: American Economic Review (cit. on pp. 2, 4, 13).

- (2004). "Monetary policy rules, macroeconomic stability, and inflation: a view from the trenches". In: Journal of Money, Credit, and Banking (cit. on pp. 2, 4, 13).

Peek, Joe, Eric S. Rosengren, and Geoffrey M. B. Tootell (2016). “Does Fed policy reveal a ternary mandate?" In: FRB of Boston WP 16-11 (cit. on p. 2).

Primiceri, Giorgio E. (2005). "Time varying structural vector autoregressions and monetary policy". In: Review of Economic Studies (cit. on pp. 2, 6, 9).

Sims, Christopher A. and Tao Zha (2006). "Were there regime switches in US monetary policy?" In: American Economic Review (cit. on p. 2).

Sullivan, Peter (2016). “Qualitative Taylor rule". In: WP (cit. on p. 2).

Svensson, Lars E. O. (2017a). "Cost-benefit analysis of leaning against the wind". In: Journal of Monetary Economics (cit. on p. 2). 
Svensson, Lars E. O. (2017b). "Leaning against the wind: costs and benefits, effects on debt, leaning in DSGE models, and a framework for comparison of results". In: International Journal of Central Banking (cit. on p. 2).

Taylor, John B. (1993). "Discretion versus policy rules in practice". In: CarnegieRochester Conference Series on Public Policy (cit. on pp. 1, 7).

Walsh, Carl E. (2003). Monetary Theory and Policy (cit. on p. 1).

Wischnewsky, Arina, David-Jan Jansen, and Matthias Neuenkirch (2019). "Financial stability and the Fed: evidence from congressional hearings". In: CESifo WP 7657 (cit. on p. 2).

Woodford, Micheal (2003). Interest and Prices: Foundations of a Theory of Monetary Policy (cit. on p. 1).

$\mathrm{Wu}$, Jing Cynthia and Fan Dora Xia (2016). "Measuring the macroeconomic impact of monetary policy at the zero lower bound". In: Journal of Money, Credit and Banking (cit. on p. 3). 
Appendix 


\section{A Data sources and transformations}

\begin{tabular}{|l|l|l|c|l|l|}
\hline Variable & Source & Mnemonics & type & transformation & link \\
\hline \hline FFR & $\begin{array}{l}\text { St. Louis } \\
\text { Fed }\end{array}$ & FEDFUNDS & rate & $\begin{array}{l}\text { aggregated to } \\
\text { quarters }\end{array}$ & FRED API \\
\hline Deflator & Phil Fed & gPGDP & rate & $\begin{array}{l}\text { filtered to latest } \\
\text { observation for } \\
\text { each quarter }\end{array}$ & xlsx, doc \\
\hline CPI & Phil Fed & gPCPI & rate & $\begin{array}{l}\text { filtered to latest } \\
\text { observation for } \\
\text { each quarter }\end{array}$ & xlsx, doc \\
\hline Core & Phil Fed & gPCPIX & rate & $\begin{array}{l}\text { filtered to latest } \\
\text { observation for } \\
\text { each quarter }\end{array}$ & xlsx, doc \\
\hline Realtime y-gap & Phil Fed & ROUTPUT & bls of \$ & $\begin{array}{l}\text { regressed to } \\
\text { quadratic time } \\
\text { trend, extrapolate } \\
\text { last percentage } \\
\text { difference }\end{array}$ & xlsx \\
\hline Ex post y-gap & $\begin{array}{l}\text { St. Louis } \\
\text { Fed }\end{array}$ & $\begin{array}{l}\text { GDPPOT } \& \\
\text { GDPC1 }\end{array}$ & levels & $\begin{array}{l}\text { percentage devia- } \\
\text { tion wrt potential }\end{array}$ & FRED API \\
\hline Unemployment & Fed. Louis & UNRATE & rate & no & FRED API \\
\hline Layoff rate & $\begin{array}{l}\text { St. Louis } \\
\text { Fed }\end{array}$ & ICSA \& PAYEMS & levels & $\begin{array}{l}\text { ratio and \% } \\
\text { Fan }\end{array}$ & FRED API \\
\hline
\end{tabular}

TABLE 9: DATA DETAILS FOR THE US. FoOtNOTED SERIES START IN 2007Q1. 


\begin{tabular}{|c|c|c|c|c|c|}
\hline Variable & Source & Mnemonics & type & transformation & link \\
\hline Empl_fluct & $\begin{array}{ll}\text { St. } & \text { Louis } \\
\text { Fed } & \\
\end{array}$ & "NROU, UNRATE & pct pts rate diff & $\begin{array}{l}\text { natural } \bar{u} \text { minus } \\
\text { current } u\end{array}$ & FRED API \\
\hline BBA spread & $\begin{array}{l}\text { St. Louis } \\
\text { Fed }\end{array}$ & BAA10Y & rate & no & $\begin{array}{l}\text { FRED API } \\
\text { - discontin- } \\
\text { ued }\end{array}$ \\
\hline S\&P500 spread & Yahoo! fin & 'GSPC & rate & $\begin{array}{l}\text { difflog minus } \\
\text { tbill rate }\end{array}$ & web \\
\hline US deficit & $\begin{array}{l}\text { St. Louis } \\
\text { FED \& BEA }\end{array}$ & $\begin{array}{l}\text { M318501Q027NBEA } \\
\text { \& GDP }\end{array}$ & A \% of GDP & $\begin{array}{l}\text { from monthly to } \\
\text { quarterly and ra- } \\
\text { tio to GDP }\end{array}$ & FRED API \\
\hline debt to GDP & $\begin{array}{l}\text { St. Louis } \\
\text { FED }\end{array}$ & GFDEGDQ188S & ratio & no & FRED API \\
\hline debt level & $\begin{array}{ll}\text { St. } & \text { Louis } \\
\text { FED } & \end{array}$ & GFDEBTN & millions of $\$$ & no & FRED API \\
\hline debt growth & $\begin{array}{ll}\text { ST. } & \text { Louis } \\
\text { FED } & \end{array}$ & GFDEBTN & rate & diff $\log$ & FRED API \\
\hline debt held by FED & $\begin{array}{l}\text { St. Louis } \\
\text { FED }\end{array}$ & FDHBFRBN & billions of $\$$ & no & FRED API \\
\hline \% debt by FED & $\begin{array}{l}\text { St. Louis } \\
\text { FED }\end{array}$ & $\begin{array}{l}\text { FDHBFRBN / } \\
\text { GFDEBTN }\end{array}$ & share & ratio & FRED API \\
\hline SPF:CPI rate & Phil Fed & SPFCPI_i & incompl. panel & tidy & xlsx doc \\
\hline SPF:CORECPI ${ }^{13}$ rate & Phil Fed & SPFCORECPI_i & incompl. panel & tidy & xlsx \\
\hline SPF:PCE rate ${ }^{14}$ & Phil Fed & SPFPCE_i & incompl. panel & tidy & xlsx \\
\hline SPF:COREPCE ${ }^{15}$ & Phil Fed & SPFCOREPCE_i & incompl panel & tidy & xlsx \\
\hline SPF:BBA spr & Phil Fed & / & incompl. panel & tidy & web \\
\hline rev'd CPI & FRED & CPIAUCSL & rate & difflog ${ }^{*} 400$ & web \\
\hline rev'd deflator & FRED & GDPDEF & rate & difflog ${ }^{*} 400$ & web \\
\hline $\begin{array}{l}\text { rev'd PCE less food } \\
\text { \& energy }\end{array}$ & FRED & PCEPILFE & rate & difflog ${ }^{*} 400$ & web \\
\hline $\begin{array}{l}\text { rev'd CPI less food } \\
\text { \& energy }\end{array}$ & FRED & CPILFESL & rate & difflog ${ }^{*} 400$ & web \\
\hline
\end{tabular}

TABle 10: DATA Details FOR THE US. FoOTNOTED SERIES START IN $2007 Q 1$. 


\begin{tabular}{ccccccccc}
\hline \hline & $r_{t}$ & $r_{t-1}$ & $E_{t} \pi_{t}^{\text {defl }}$ & $E_{t} \pi_{t+1}^{\text {defl }}$ & $E_{t} \pi_{t}^{c p i}$ & $E_{t} \pi_{t+1}^{c p i}$ & $E_{t} \pi_{t}^{p c e}$ & $E_{t} \pi_{t+1}^{p c e}$ \\
\hline$r_{t}$ & 1 & 0.982 & 0.547 & 0.693 & 0.393 & 0.518 & 0.729 & 0.822 \\
$r_{t-1}$ & 0.982 & 1 & 0.549 & 0.682 & 0.356 & 0.484 & 0.735 & 0.817 \\
$E_{t} \pi_{t}^{d e f l}$ & 0.547 & 0.549 & 1 & 0.543 & 0.476 & 0.206 & 0.667 & 0.629 \\
$E_{t} \pi_{t+1}^{d e f l}$ & 0.693 & 0.682 & 0.543 & 1 & 0.410 & 0.571 & 0.727 & 0.813 \\
$E_{t} \pi_{t}^{c p i}$ & 0.393 & 0.356 & 0.476 & 0.410 & 1 & 0.493 & 0.500 & 0.431 \\
$E_{t} \pi_{t+1}^{c p i}$ & 0.518 & 0.484 & 0.206 & 0.571 & 0.493 & 1 & 0.469 & 0.582 \\
$E_{t} \pi_{t}^{p c e}$ & 0.729 & 0.735 & 0.667 & 0.727 & 0.500 & 0.469 & 1 & 0.861 \\
$E_{t} \pi_{t+1}^{p c e}$ & 0.822 & 0.817 & 0.629 & 0.813 & 0.431 & 0.582 & 0.861 & 1 \\
$E_{t} \hat{y}_{t}$ & 0.616 & 0.612 & 0.304 & 0.218 & 0.223 & 0.214 & 0.295 & 0.357 \\
$\hat{y}_{t}$ & 0.614 & 0.575 & 0.145 & 0.192 & 0.223 & 0.204 & 0.153 & 0.222 \\
$\hat{u}_{t}$ & -0.735 & -0.723 & -0.311 & -0.347 & -0.260 & -0.314 & -0.366 & -0.449 \\
SP & -0.622 & -0.629 & -0.499 & -0.406 & -0.179 & -0.292 & -0.466 & -0.533 \\
BAA & -0.623 & -0.552 & -0.311 & -0.431 & -0.471 & -0.414 & -0.399 & -0.461 \\
\hline
\end{tabular}

\begin{tabular}{cccccc}
\hline \hline & $E_{t} \hat{y}_{t}$ & $\hat{y}_{t}$ & $\hat{u}_{t}$ & $\mathrm{SP}$ & $\mathrm{BAA}$ \\
\hline$r_{t}$ & 0.616 & 0.614 & -0.735 & -0.622 & -0.623 \\
$r_{t-1}$ & 0.612 & 0.575 & -0.723 & -0.629 & -0.552 \\
$E_{t} \pi_{t}^{d e f l}$ & 0.304 & 0.145 & -0.311 & -0.499 & -0.311 \\
$E_{t} \pi_{t+1}^{d e f l}$ & 0.218 & 0.192 & -0.347 & -0.406 & -0.431 \\
$E_{t} \pi_{t}^{c p i}$ & 0.223 & 0.223 & -0.260 & -0.179 & -0.471 \\
$E_{t} \pi_{t+1}^{c p i}$ & 0.214 & 0.204 & -0.314 & -0.292 & -0.414 \\
$E_{t} \pi_{t}^{p c c}$ & 0.295 & 0.153 & -0.366 & -0.466 & -0.399 \\
$E_{t} \pi_{t+1}^{p c e}$ & 0.357 & 0.222 & -0.449 & -0.533 & -0.461 \\
$E_{t} \hat{y}_{t}$ & 1 & 0.736 & -0.881 & -0.551 & -0.355 \\
$\hat{y}_{t}$ & 0.736 & 1 & -0.889 & -0.393 & -0.557 \\
$\hat{u}_{t}$ & -0.881 & -0.889 & 1 & 0.543 & 0.533 \\
SP & -0.551 & -0.393 & 0.543 & 1 & 0.235 \\
BAA & -0.355 & -0.557 & 0.533 & 0.235 & 1 \\
\hline
\end{tabular}

TABLE 11: CORRELATIONS: $r$ IS THE FFR, $E_{t} \pi^{i}$ IS NOW- OR ONE PERIOD AHEAD FORECAST FOR INFLATION MEASURE $i, E_{t} \hat{y}_{t}$ IS REAL TIME OUTPUT GAP, $\hat{y}_{t}$ IS CAPACITY UTILISATION, $\hat{u}_{t}$ IS FLUCTUATIONS AROUND THE NATURAL UNEMPLOYMENT RATE, SP AND BAA ARE THE SPREADS. 


\section{B Empirical appendix}

\section{B.1 Output gap}

We detail the econometric derivation of the real time output gap from the Greenbook dataset. This dataset offers data and forecasts prepared by the Federal Reserve System staff for the Federal Open Market Committee meetings, where policy rate decisions are discussed. To gauge the output gap at any date $t$, we select all observations up to time $t$, run a simple quadratic time trend and keep the last observation residual. This term is then normalized as percentage deviation from the computed trend and used as output gap observation. The algorithm is the following:

1 set a number $j$ of observations sufficiently high to compute precise estimates

2 for all $t$ in $[j, T]$ run the following routine

$i$ sub-select observations in the $[j, t]$ interval

ii estimate $y_{s}=\alpha_{1} s+\alpha_{2} s^{2}+\epsilon_{s}, s=j, j+1, \ldots, t$; recover fitted values $\hat{y}_{s}$

iii compute gap $_{t}=\left(\frac{y_{t}-\hat{y}_{t}}{y_{t}}\right) \times 100=\frac{\hat{\epsilon}_{t}}{y_{t}} \times 100$; keep the latest observation/nowcast prior to the FOMC meeting

3 stack and date all gap to construct the real time output gap variable

\section{B.2 Full sample regression: residuals}

Fig.(4) plots the residuals generated from the regression on the full sample. As OLS sort of averages over the full sample, sudden and ample fluctuations in the residuals point to observations where the model underperforms. This occurs typically in the late '70s, late ' 80 , and around the GFC period. 

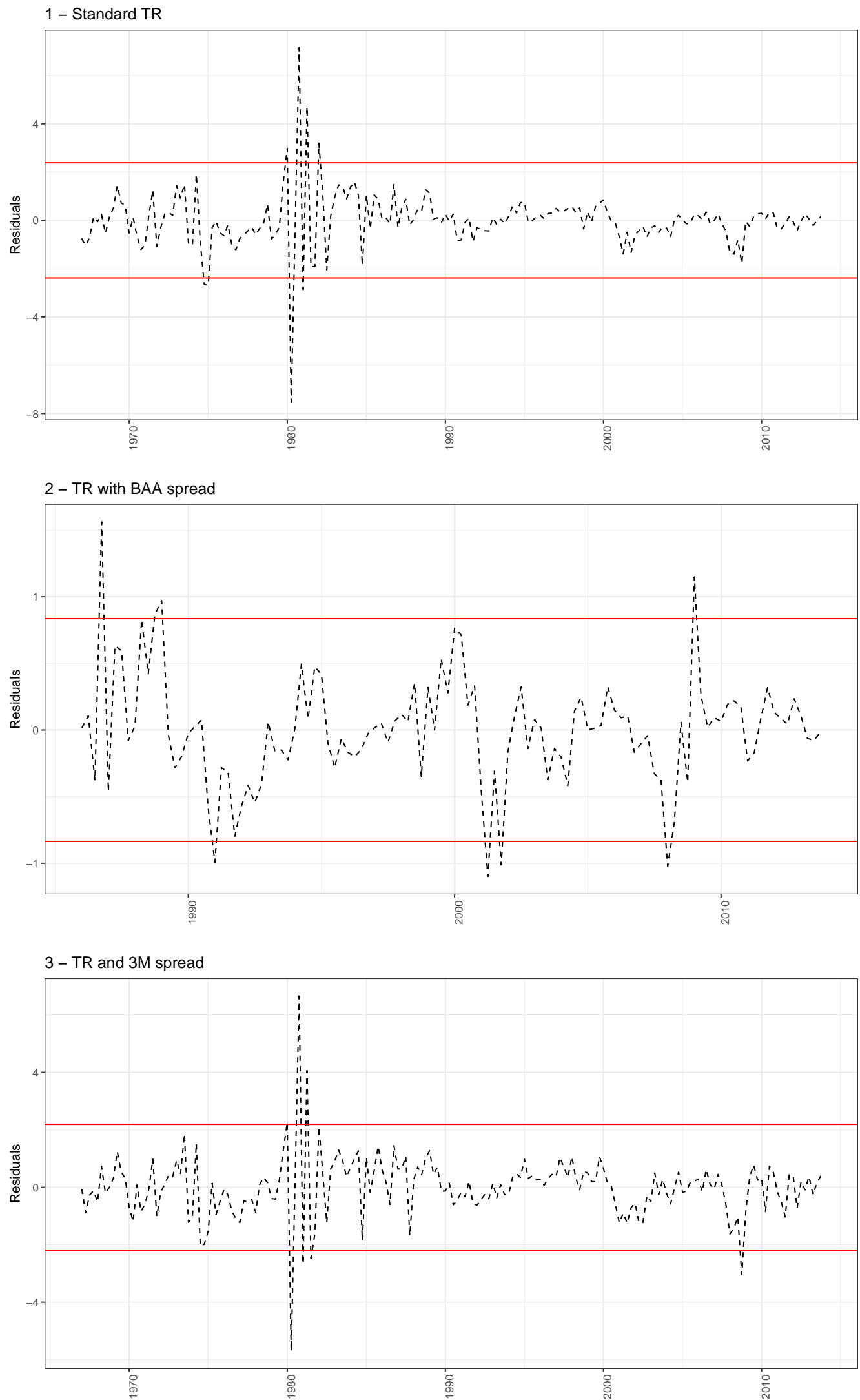

Figure 4: ResiduAls PLOT FOR THE THREE SPECIFICATIONS. DASHED LINE DEPICTS SINGLE RESIDUALS AS TIME SERIES, SOLID HORIZONTAL LINES CONTOUR THE 2-SDS AREA AROUND ZERO, THE EXPECTED - AND EMPIRICAL - RESIDUALS MEAN. 


\section{B.3 CUSUM tests plots}

This section presents the CUSUM plots for the eight specifications of the Taylor rule studied in Section (3). The solid black line marks the cumulative sum of residuals, whilst the red lines define the significance areas, in which the residuals sum signals a change in the underlying data generating process. 
1 - Standard TR: OLS-based CUSUM test

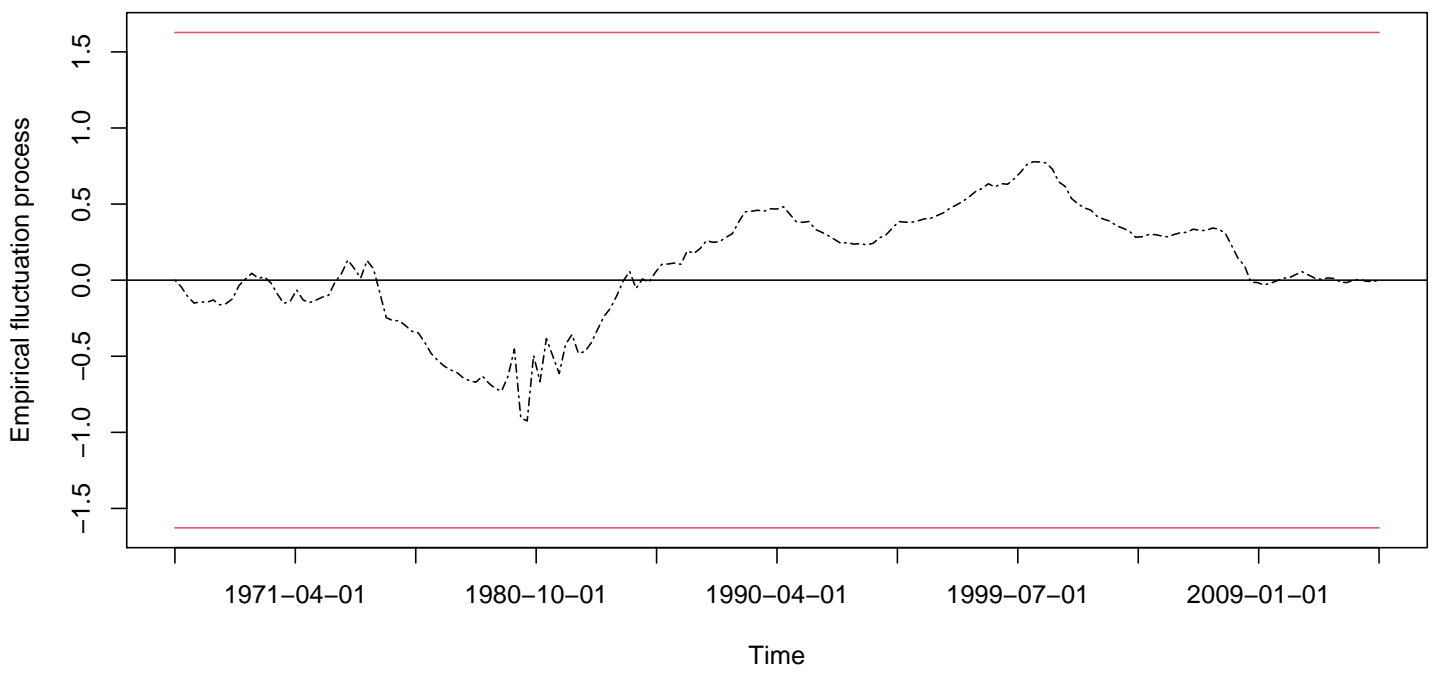

2 - TR with BAA spread: OLS-based CUSUM test

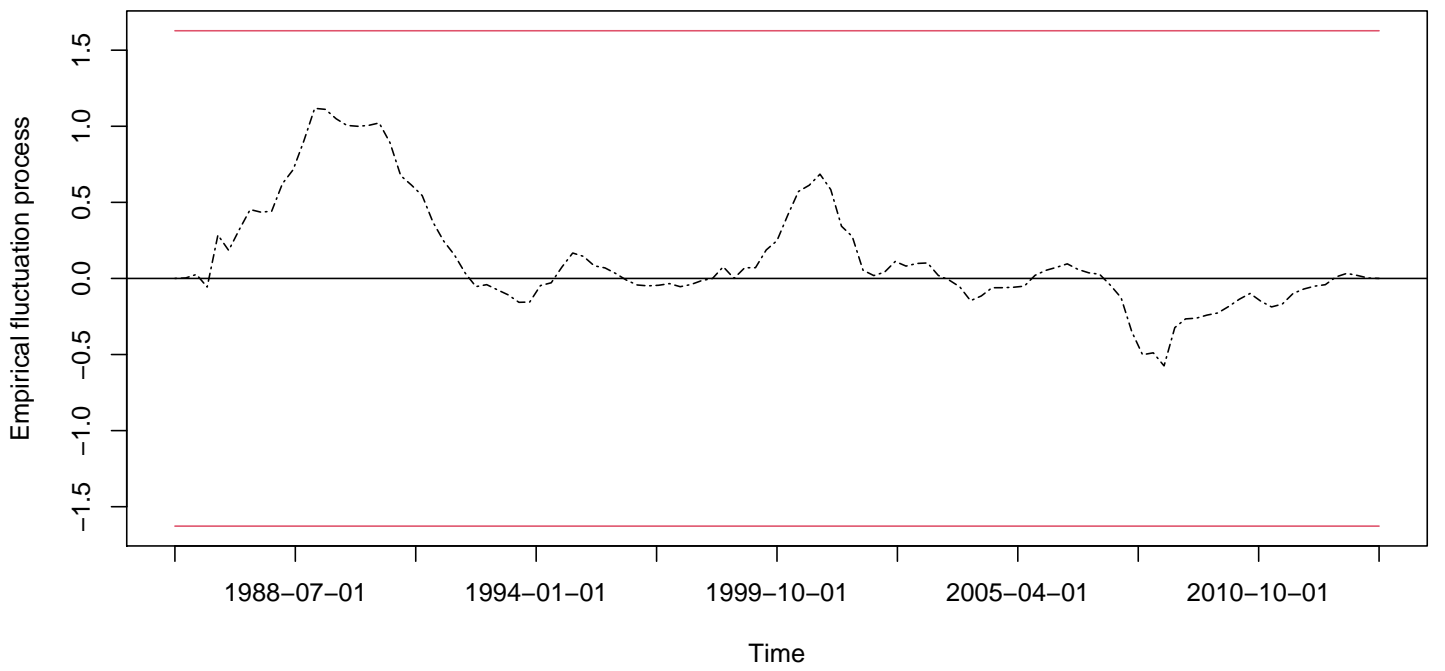

3 - TR and 3M spread: OLS-based CUSUM test

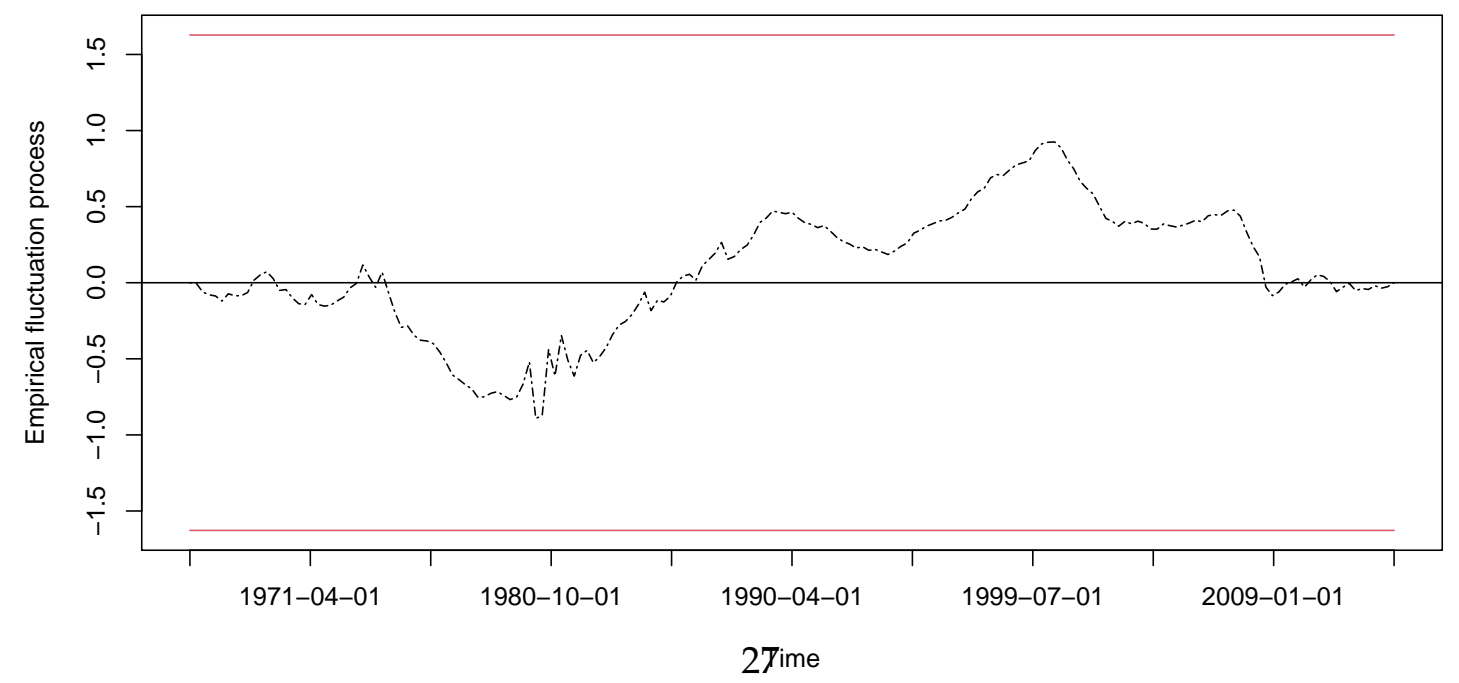

FIGURE 5: DASHED LINE DEPICTS CUMULATIVE SUM OF RESIDUALS, SOLID HORIZONTAL LINES MARK THE SIGNIFICANCE AREA FOR CHANGES IN THE UNDERLYING DGP. 